\title{
Study of intraventricular conduction times in patients with left bundle-branch block and left axis deviation and in patients with left bundle- branch block and normal QRS axis using His bundle electrograms
}

\author{
Roworth A. J. Spurrell, Dennis M. Krikler, and Edgar Sowton \\ From the Department of Cardiology, Guy's Hospital, and the \\ Prince of Wales Hospital, London
}

\begin{abstract}
His bundle electrograms have been recorded in 5 patients with left bundle-branch block and additional left anterior hemiblock and in 4 patients with left bundle-branch block and a normal $Q R S$ axis. The finding of a prolonged intraventricular conduction time in the patients with left bundle-branch block and left anterior hemiblock indicates delayed conduction down the right bundle-branch, and therefore more widespread disease of the conduction system than is apparent from the external electrocardiogram. The intraventricular conduction time was normal in the 4 patients with left bundle-branch block and a normal $Q R S$ axis. It is suggested that the recording of His bundle electrograms in patients with left bundle-branch block and left axis deviation is a useful technique for assessing conduction down the right bundle-branch and if this is found to be impaired, especially in patients with a history of syncopal episodes, this could constitute an indication for the implantation of a pacemaker.
\end{abstract}

The presence of left bundle-branch block is generally considered to be due to organic heart disease and to carry a serious prognosis (Wood, 1968). However, there are published reports of left bundle-branch block occurring in patients in the absence of organic heart disease (Campbell, 1969; White and Donovan, 1967; Wolfram, I95I). In order to clarify this situation further we have measured intraventricular conduction times using His bundle electrograms in patients with left bundlebranch block in association with a normal mean frontal plane QRS axis and in patients with left bundle-branch block and a mean frontal plane QRS axis of greater than $-30^{\circ}$ indicating additional left anterior hemiblock (Pryor and Blount, 1966; Rosenbaum, 1969).

\section{Patients and methods}

Nine patients were studied, 7 men and 2 women. Three patients (Cases I, 2, and 3) gave a history of syncopal episodes, 2 patients (Cases 7 and 8 ) gave a history of angina pectoris, and 3 patients

Received 26 April 1972.
(Cases 5, 6, and 9) were symptomless. Only I patient (Case 4) was taking digoxin and diuretics. The details of the patients and their electrocardiograms are shown in Table $I$.

All 9 patients had complete left bundle-branch block. Cases $1,2,3,4$, and 5 showed left axis deviation on their electrocardiogram and Cases $6,7,8$, and 9 had a normal mean frontal plane QRS axis.

In each patient a $\mathrm{His}$ bundle electrogram was recorded using the technique described by Scherlag et al. (1969). A bipolar electrode catheter was introduced into a femoral vein by direct puncture and passed to the right ventricle under fluoroscopic control. A second bipolar catheter was passed to the right atrium via a brachial vein; this was connected to a Multitone external pacemaker and used for atrial pacing. The catheter in the right ventricle was connected to the electrocardiogram input of a Cambridge photographic recorder. Records were taken with the frequency response set at 80-500 cycles/second and at a paper speed of $100 \mathrm{~mm} / \mathrm{second}$. An external electrocardiogram was recorded simultaneously. The catheter in the right ventricle was withdrawn across the tricuspid valve until the bi- or triphasic spike of the His potential was seen between the $P$ wave and the QRS complex of the external elec- 
TABLE I Details of patients and their electrocardiograms

\begin{tabular}{llllllll}
\hline $\begin{array}{l}\text { Case } \\
\text { No. }\end{array}$ & Age & Sex & Clinical diagnosis & Symptoms & PR interval & $\begin{array}{l}\text { Left bundle-branch Mean frontal } \\
\text { block and QRS } \\
\text { width }\end{array}$ & $\begin{array}{c}\text { plane QRS } \\
\text { axis }\end{array}$ \\
\hline I & 41 & M & Cardiomyopathy & Syncope & 0.36 & 0.16 & $-40^{\circ}$ \\
2 & 64 & M & Coronary artery disease & Syncope & 0.24 & 0.14 & $-30^{\circ}$ \\
3 & 68 & F & Coronary artery disease & Syncope & 0.20 & 0.16 & $-40^{\circ}$ \\
4 & 58 & M & Cardiomyopathy & Heart failure & 0.17 & 0.13 & $-40^{\circ}$ \\
5 & 40 & M & No organic heart disease & Nil & 0.20 & 0.16 & $-40^{\circ}$ \\
6 & 54 & F & Hypertension & Nil & 0.19 & 0.16 & $+20^{\circ}$ \\
7 & 62 & M & Coronary artery disease & Angina & 0.15 & 0.16 & $+30^{\circ}$ \\
8 & 76 & M & Coronary artery disease & Angina & Atrial & 0.17 & $0^{\circ}$ \\
& & & & & fibrillation & & $+20^{\circ}$ \\
\hline
\end{tabular}

trocardiogram. Bipolar recordings were obtained. Recordings were taken while in sinus rhythm and during atrial pacing up to a rate of 160 a minute except in the patient with atrial fibrillation. Finally, in each patient the His bundle was paced using the bipolar catheter placed in the region of the His bundle and connecting it to a Multitone external pacemaker. His bundle pacing was carried out up to a rate of 160 a minute. The following measurements were made from the records obtained.

P-His: The time in msec between the onset of the $\mathbf{P}$ wave on the external electrocardiogram and the first deflection of the His potential on the intracardiac. recording.

St-His: The time in msec between the atrial pacing stimulus as seen on the external electrocardiogram and the onset of the His potential as seen on the intracardiac recording.

His-Q: The time in msec between the onset of the His potential and the onset of QRS complex on the external electrocardiogram.

RR interval: The time in msec between two successive $\mathbf{R}$ waves on the external electrocardiogram.

The normal P-His interval was taken as 80-r40 msec for heart rates below 80 a minute. The normal His-Q interval was taken as $35-55$ msec. These figures are based upon unpublished data of our own, confirming reported values from Damato et al. (1969).

The results of the His bundle electrograms are shown in Table 2.

Fig. I-6 are electrocardiograms and His bundle recordings from Cases 5 and 6 and are explained in the text below each recording.

\section{Results}

Electrocardiograms Cases 6 to 9 all had left bundle-branch block and a normal mean frontal plane QRS axis. This could indicate
TABLE 2 Details of His bundle electrograms

\begin{tabular}{|c|c|c|c|c|c|}
\hline $\begin{array}{l}\text { Case } \\
\text { No. }\end{array}$ & $\begin{array}{l}P-H i s \text { sinus } \\
\text { rhythm }\end{array}$ & $\begin{array}{l}\text { St-His atrial } \\
\text { pacing }\end{array}$ & $H i s-Q$ & $\begin{array}{l}R R \\
\text { interval }\end{array}$ & Rate/min \\
\hline $\begin{array}{l}\mathbf{I} \\
\mathbf{2}\end{array}$ & $\begin{array}{l}239 \\
110\end{array}$ & $\begin{array}{l}\text { Unsuccessful } \\
180 \\
195 \\
218\end{array}$ & $\begin{array}{l}75 \\
70 \\
70 \\
70 \\
70\end{array}$ & $\begin{array}{l}850 \\
740 \\
600 \\
510 \\
440\end{array}$ & $\begin{array}{r}99 \\
81 \\
100 \\
115 \\
136\end{array}$ \\
\hline 3 & 130 & $\begin{array}{l}170 \\
210 \\
215 \\
285\end{array}$ & $\begin{array}{l}75 \\
70 \\
70 \\
70 \\
70\end{array}$ & $\begin{array}{l}755 \\
860 \\
630 \\
505 \\
400\end{array}$ & $\begin{array}{r}80 \\
70 \\
95 \\
120 \\
150\end{array}$ \\
\hline 4 & 95 & $\begin{array}{l}145 \\
160\end{array}$ & $\begin{array}{l}95 \\
90 \\
95\end{array}$ & $\begin{array}{l}790 \\
600 \\
480\end{array}$ & $\begin{array}{r}76 \\
100 \\
124\end{array}$ \\
\hline 5 & 75 & $\begin{array}{r}95 \\
120 \\
120\end{array}$ & $\begin{array}{l}95 \\
90 \\
95 \\
95\end{array}$ & $\begin{array}{l}725 \\
600 \\
495 \\
420\end{array}$ & $\begin{array}{r}84 \\
100 \\
120 \\
145\end{array}$ \\
\hline 6 & I 43 & $\begin{array}{l}160 \\
185\end{array}$ & $\begin{array}{l}40 \\
40 \\
35\end{array}$ & $\begin{array}{l}720 \\
610 \\
430\end{array}$ & $\begin{array}{r}84 \\
99 \\
140\end{array}$ \\
\hline 7 & 95 & $\begin{array}{l}157 \\
160\end{array}$ & $\begin{array}{l}45 \\
48 \\
45\end{array}$ & $\begin{array}{l}555 \\
430 \\
400\end{array}$ & $\begin{array}{l}107 \\
140 \\
150\end{array}$ \\
\hline 8 & $\begin{array}{l}\text { Atrial } \\
\text { fibrillation }\end{array}$ & - & 55 & - & 70 \\
\hline 9 & 86 & $\begin{array}{l}104 \\
115 \\
128\end{array}$ & $\begin{array}{l}43 \\
46 \\
46 \\
45\end{array}$ & $\begin{array}{l}630 \\
500 \\
440 \\
400\end{array}$ & $\begin{array}{r}95 \\
120 \\
135 \\
130\end{array}$ \\
\hline
\end{tabular}


block in the left bundle before it divides into its anterior and posterior divisions (Rosenbaum, 1969). These 4 patients all had normal PR intervals indicating normal conduction times in the atria, AV node, and right bundle.

Cases I to 5 all had left bundle-branch block and left axis deviation. This indicates additional block in the anterior division of the left bundle (Pryor and Blount, 1966; Rosenbaum, I969). Two patients (Cases I and 2) had long PR intervals indicating either delayed conduction in the atria and AV node or in the right bundle-branch.

His bundle electrograms The His bundle was recorded in all 9 patients and atrial pacing was carried out in all patients except Cases $\mathrm{I}$ and 8.

The P-His interval in sinus rhythm was normal in all patients except Case $I$ indicating a normal conduction time through the atria and AV node. In Case I the P-His was prolonged indicating delayed conduction proximal to the bundle of His. On atrial pacing the St-His interval increased with increasing heart rates as expected (Damato et al., 1969).

The His- $Q$ interval was prolonged in the patients with left bundle-branch block and additional left anterior hemiblock (Cases I-5). This interval remained constant during atrial
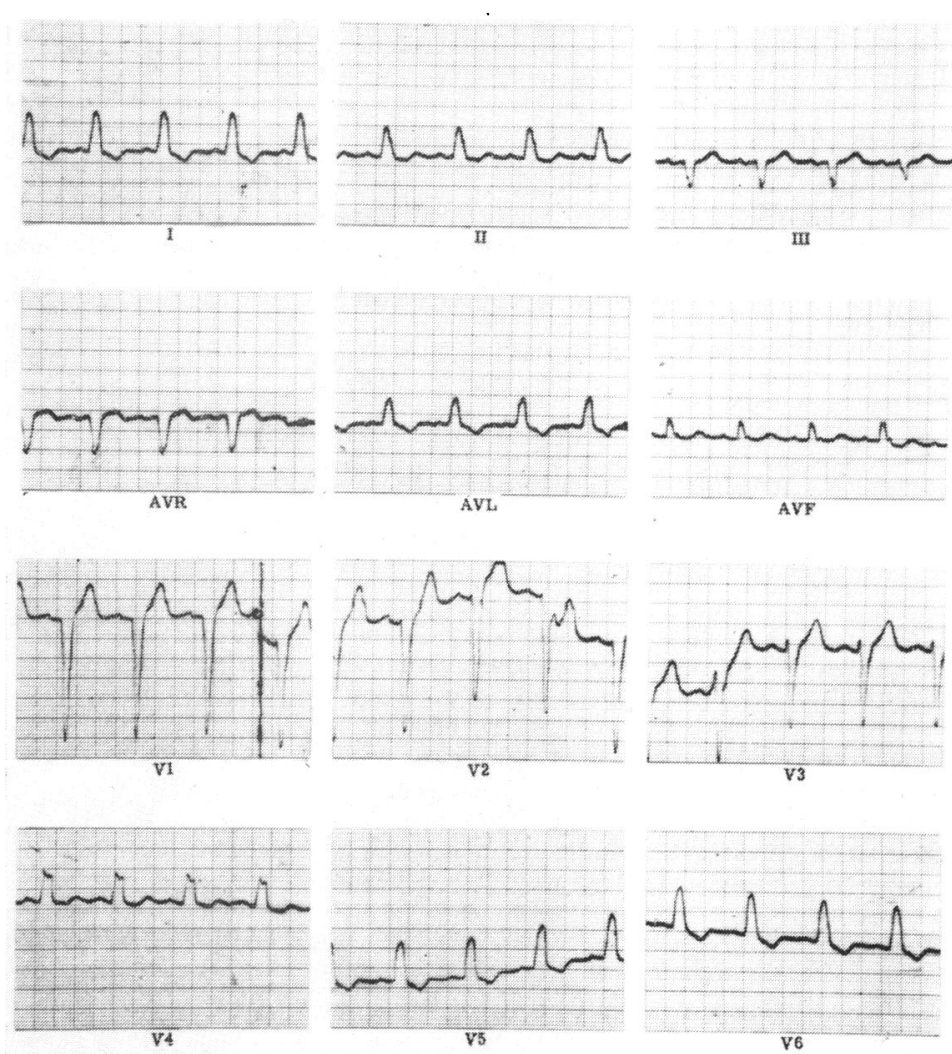

FIG. I Electrocardiogram from Case 6.

FIG. 2 His bundle electrogram from Case 6 recorded during sinus rhythm. HBE $=$ His bundle electrogram; $H=H$ is bundle depolarization; $V=$ ventricular depolarization.
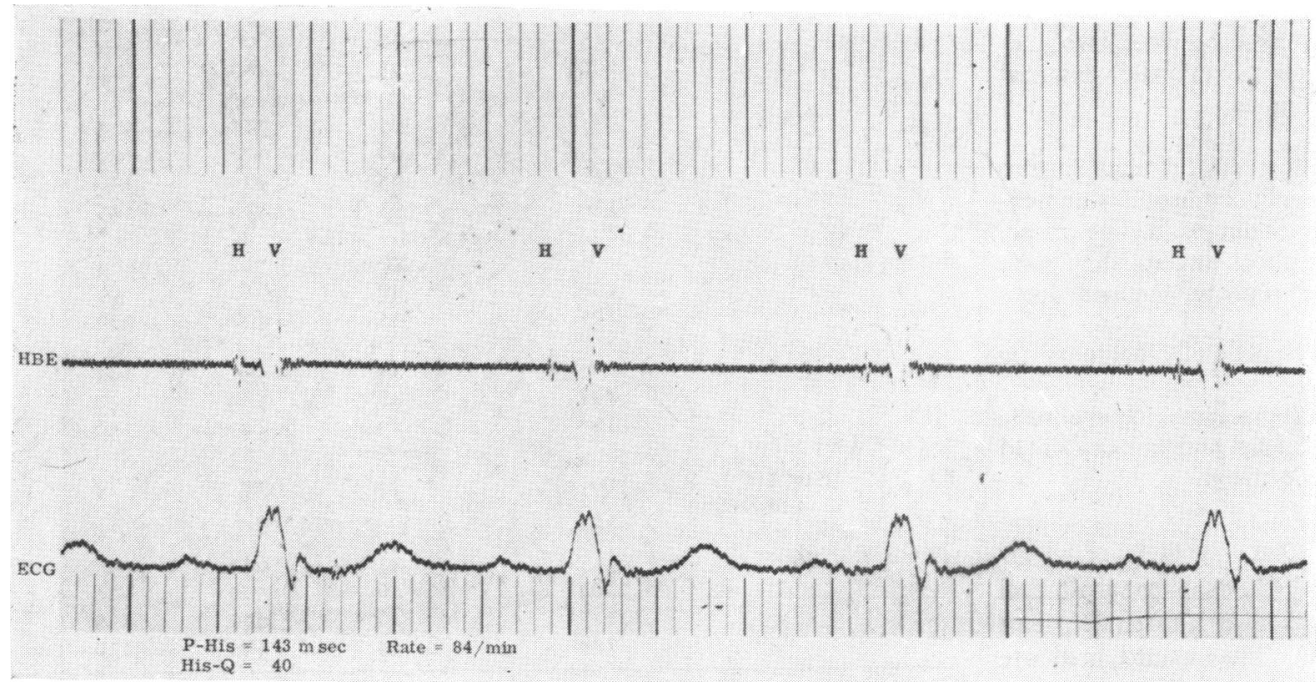
pacing (the normal response to atrial pacing (Damato et al., 1969)). The prolonged His-Q interval in these patients was interpreted as indicating further conduction delay down the right bundle-branch, and therefore probable additional disease of this bundle-branch.

The His- $Q$ interval was normal in Cases 6 to 9. These patients all had a normal mean frontal plane QRS axis and therefore no evidence of additional disease in the anterior division of the left bundle-branch. The normal His-Q interval in this group of patients with left bundle-branch block was interpreted as indicating normal conduction down the right bundle.

Case 5 was symptomless but was found to have a prolonged His- $Q$ interval. This patient developed complete heart block during the investigation and subsequently required the implantation of a permanent pacemaker.

\section{Discussion}

Patients with left bundle-branch block and a normal mean frontal plane $Q R S$ axis may have block either proximal to the bifurcation of the left main bundle or more distal block in both the anterior and posterior divisions of the left bundle-branch (Rosenbaum, 1969). We have recorded His bundle electrograms in 4 patients showing left bundle-branch block and a normal axis, and in all 4 patients the intraventricular conduction time as assessed by the His- $\mathrm{Q}$ interval has been normal. This indicates that, though the left bundle is blocked, conduction down the right bundle, upon which ventricular activation is dependent, is normal.

In the 5 patients with left bundle-branch block and left axis deviation there is additional block in the anterior division of the left bundle (Pryor and Blount, 1966; Rosenbaum, I969), or the impulse from the right bundle crosses the septum into the conduction tissue of the left ventricle low down near the apex thereby producing left axis deviation (Friedberg and Schamroth, 1970). Whichever mechanism is correct, left axis deviation in the presence of left bundle-branch block suggests more extensive disease of the left bundlebranches than when the mean frontal plane QRS axis is normal. The intraventricular conduction time in these 5 patients was found to be abnormally long. As activation of the ventricles in this group of patients is via the right bundle-branch then the finding of a long

FIG. 4 Electrocardiogram from Case 5.

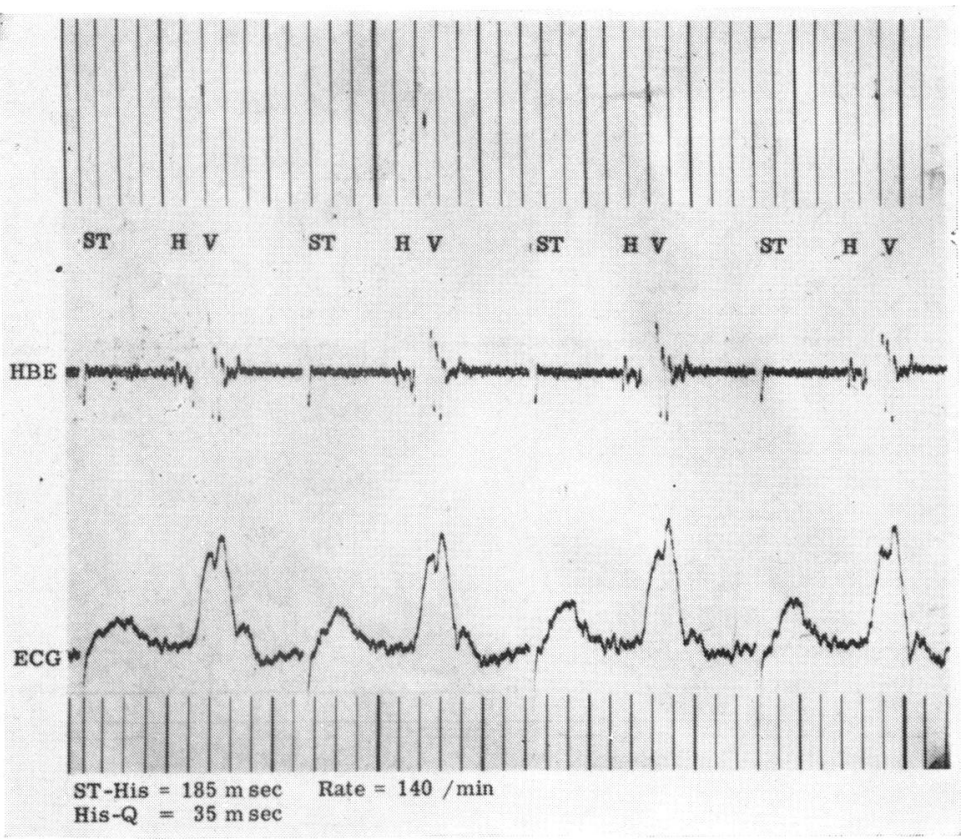

FIG. 3 His bundle electrograms from Case 6 recorded during atrial pacing at a rate of 140 a minute.
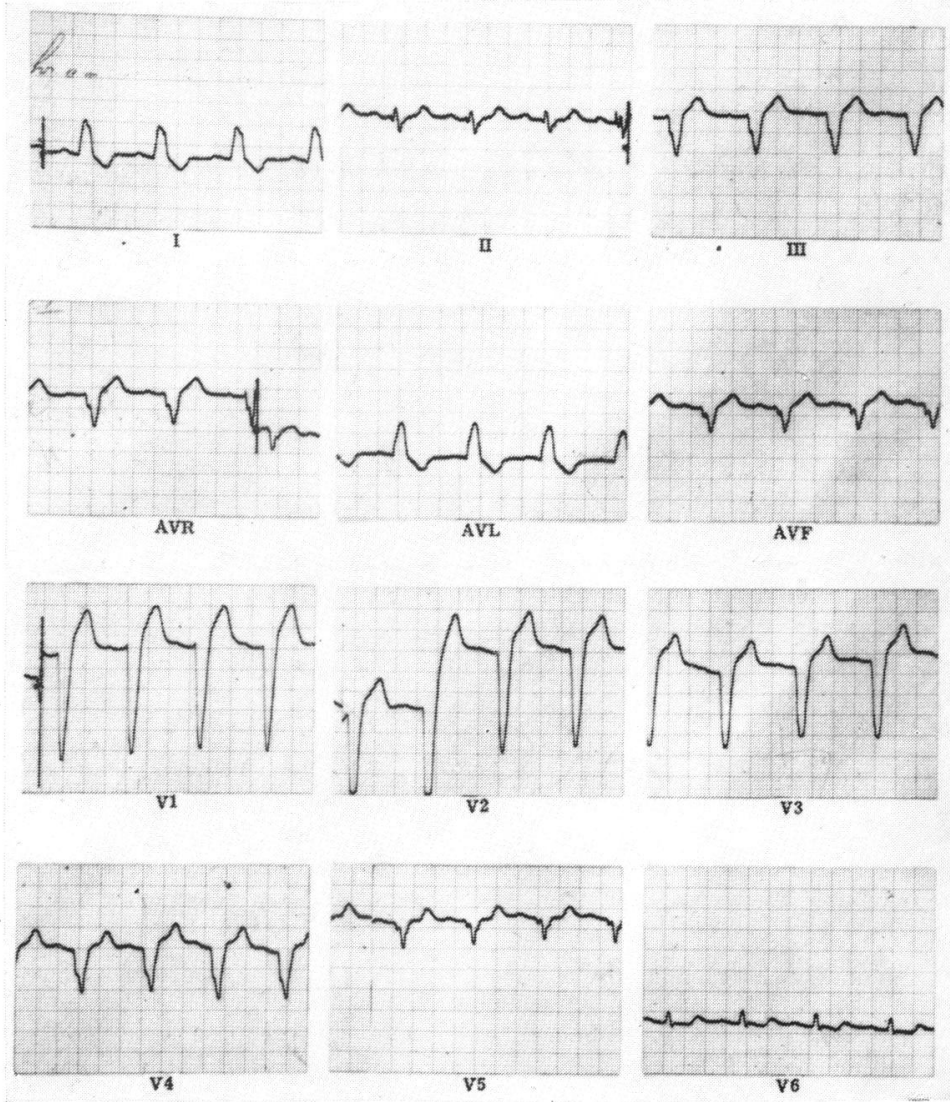

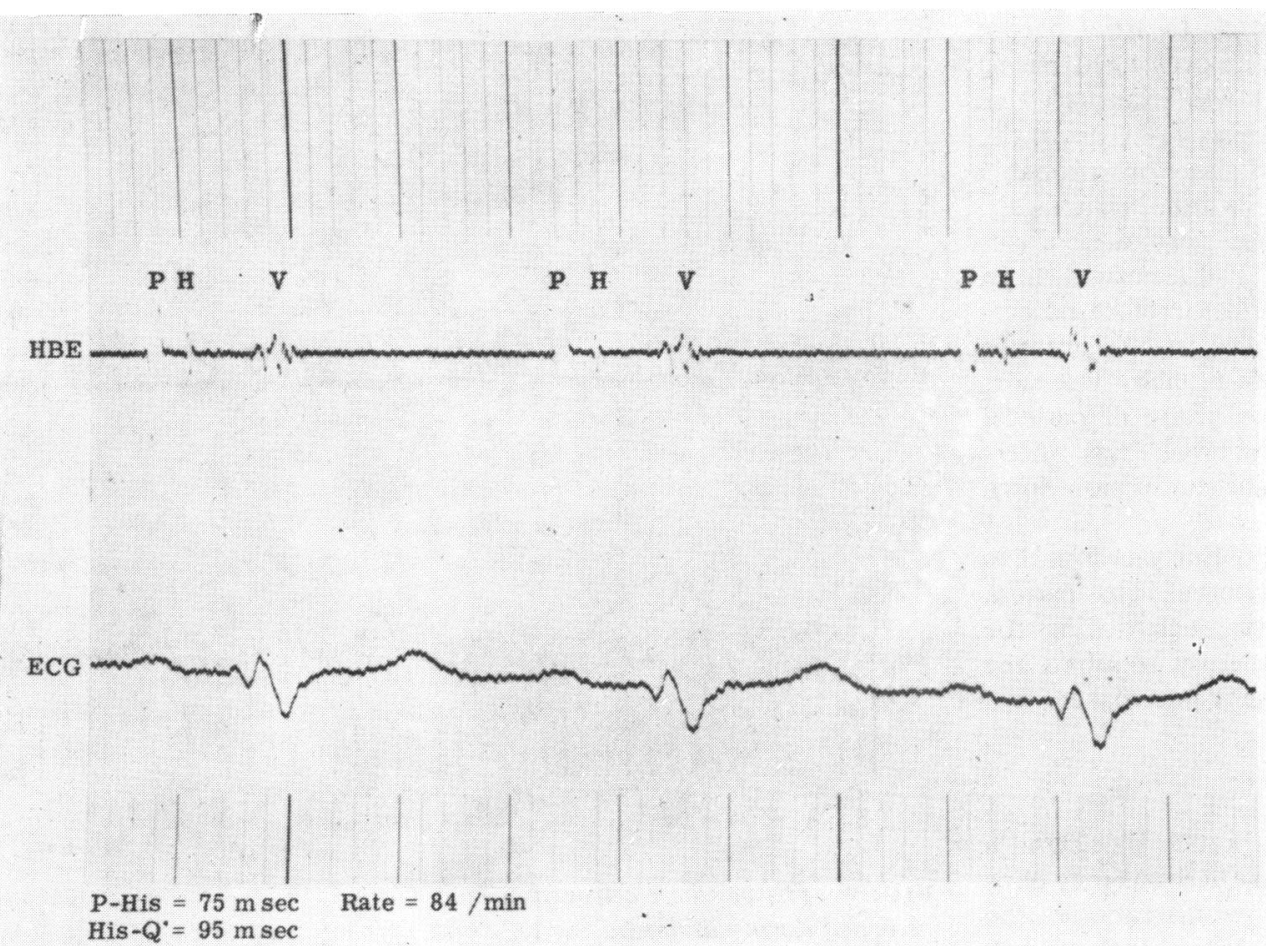

FIG. 5 His bundle electrogram from Case 5 recorded during sinus rhythm.

FIG. 6 His bundle electrogram recorded from Case 5 during atrial pacing at a rate of 145 a minute.
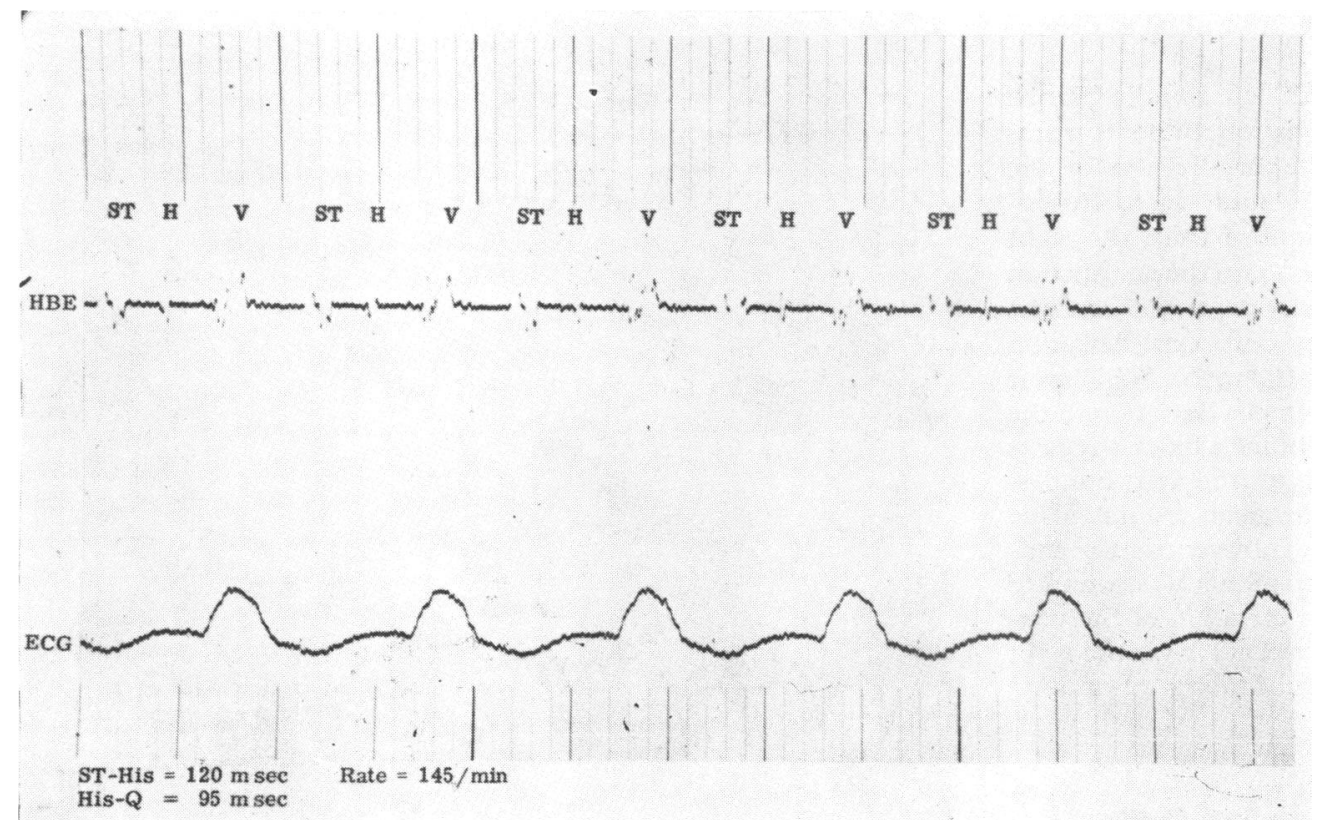
His- $Q$ interval indicates that there is additional delay in the right bundle and that trifascicular disease is present. The finding of a long PR interval in 2 of these patients with left bundle-branch block and additional left anterior hemiblock is further evidence that trifascicular disease is present (Rosenbaum et al., 1969; Haft et al., 1971). However, in Case I the PR interval of 0.36 was accounted for partly by conduction delay proximal to the bundle of His probably in the AV node as indicated by the finding of a long P-His interval on the His bundle electrogram and partly by an intraventricular conduction delay as indicated by the long His- $Q$ interval.

It is interesting that of the 5 patients with left bundle-branch block, left anterior hemiblock, and a prolonged intraventricular conduction time, 3 gave a history of syncopal episodes which might be accounted for by the development of intermittent complete heart block and Adams-Stokes attacks.

Case 5 deserves a separate discussion. $\mathrm{He}$ was a 40-year-old man with no relevant history. Two years before his present investigation he had been shown to have rate dependent left bundle-branch block and left axis deviation. His case, along with one other, was described by Krikler and Lefevre (I970) as representing left bundle-branch block occurring without obvious heart disease. These authors commented that left bundle-branch block in the absence of obvious organic heart disease did not necessarily herald a serious prognosis though they stated that a careful follow-up would be necessary to verify this. A His bundle electrogram was recorded in this patient 2 years after his case was first reported and a prolonged intraventricular conduction time was measured. Cardiac catheterization and coronary angiography at this time was normal. During the investigation complete heart block developed and then ventricular asystole. The patient subsequently returned to sinus rhythm; however, it was felt necessary to implant a demand pacemaker.

These results suggest that the presence of left bundle-branch block in association with additional left anterior hemiblock may indicate that more widespread disease of the conduction tissue is present than would be apparent from the external electrocardiogram, and the finding of a prolonged intraventricular conduction time in these patients can be ex- plained by additional disease of the right bundle-branch. The recording of a His bundle electrogram in this group of patients provides a valuable method for assessing conduction down the right bundle-branch. Should the conduction time be found to be delayed in the right bundle (as evidenced by a prolonged His- $Q$ interval), then a case can be made for the insertion of a pacemaker at this time, despite the presence of sinus rhythm. A history of syncopal episodes is a strong additional feature in favour of pacemaker implantation.

Part of this work was supported by a grant from the British Heart Foundation.

\section{References}

Campbell, M. (1969). The outlook with bundle-branch block. British Heart fournal, 31, 575.

Damato, A. N., Lau, S. H., Helfant, R. H., Stein, E., Berkowitz, W. D., and Cohen, S. I. (I969). Study of atrioventricular conduction in man using electrode catheter recordings of His bundle activity. Circulation, 39, 287.

Friedberg, H. D., and Schamroth, L. (1970). Wenckebach phenomenon in left bundle branch block. American fournal of Cardiology, 26, 550 .

Haft, J. I., Weinstock, M., DeGuia, R., Gupta, P. K., and Fano, A. (197I). Assessment of atrioventricular conduction in left and right bundle branch block using His bundle electrograms and atrial pacing. American fournal of Cardiology, 27, 474.

Krikler, D. M., and Lefevre, D. (1970). Intermittent left bundle-branch block, without obvious heart disease. Lancet, $\mathbf{1}, 498$.

Pryor, R., and Blount, S. G., Jr. (1966). The clinical significance of true left axis deviation. American Heart fournal, 72, 391.

Rosenbaum, M. B. (1969). Types of left bundle branch block and their clinical significance. Fournal of Electrocardiology, 2, 197.

Rosenbaum, M. B. Elizari, M. V., Lazzari, J. O., Nau, G. J., Levi, R. J., and Halpern, M. S. (1969). Intraventricular trifascicular blocks. American Heart fournal, 78, 45I.

Scherlag, B. J., Lau, S. H., Helfant, R. H., Berkowitz, W. D., Stein, E., and Damato, A. N. (1969). Catheter technique for recording His bundle activity in man. Circulation, 39, 13.

White, P. D., and Donovan, H. (1967). Hearts - Their Long Follow-up, p. 281. W. B. Saunders, London.

Wolfram, J. (I95I). Bundle branch block without sig nificant heart disease. American Heart fournal, 41, 656.

Wood, P. (1968). Diseases of the Heart and Circulation, 3rd ed., p. 252. Eyre and Spottiswoode, London.

Requests for reprints to Dr. Roworth A. J. Spurrell, Cardiac Department, Guy's Hospital, London SEI 9RT. 